OPEN ACCESS

International Journal of Management \& Entrepreneurship Research

P-ISSN: 2664-3588, E-ISSN: 2664-3596

Volume 2, Issue 7, P.No. 458-462, December, 2020

Fair East Publishers

Journal Homepage: www.fepbl.com/index.php/ijmer

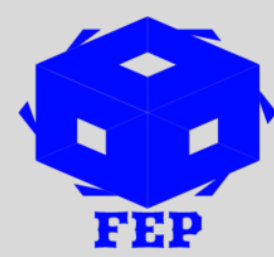

\title{
EQUITY AND PRODUCTS OF SMEs: A CRITICAL LITERATURE REVIEW IN A MARKETING PERSPECTIVE
}

\author{
Dr. Théophile Bindeouè Nassè $\grave{1}^{1,2}$ \\ ${ }^{1}$ Simon Diedong Dombo University of Business and Integrated Development Studies \\ (Department of Marketing and Entrepreneurship, Ghana) \\ ${ }^{2}$ Saint Thomas d'Aquin University, Ouagadougou (Burkina Faso)
}

Corresponding Author: Dr. Théophile Bindeouè Nassè

Corresponding Author Email: nassetheophile2009@gmail.com

Article Received: 08-11-20 Accepted: 13-12-20

Published: $30-12-20$

Licensing Details: Author retains the right of this article. The article is distributed under the terms (http://www.creativecommons.org/licences/by-nc/4.0/) of the Creative Commons Attribution-Non Commercial 4.0 License which permits non-commercial use, reproduction and distribution of the work without further permission provided the original work is attributed as specified on the Journal open access page.

\section{ABSTRACT}

The main purpose of this paper is to review the multiple understandings of the concept of equity and its different underpinning theories in a business to customer context. The design of this research is based on a mere documentary analysis and some observations. However, the findings show that equity is mainly understood as fairness, as well as distributive justice in the business setting.

This paper serves to remind manufacturers and managers that they should abide to fair practices in order to offer some good quality products or services as well as some very fair prices that are in line with the customer expectations in terms of norms, requirements, and needs.

Keywords: Equity, customer, distributive justice, marketing.

\section{INTRODUCTION}

The concept of equity is originated from the Latin concepts "aequitas"' and "aequus", 'that bear the notions of "equality", "justice" and "impartiality". Equity is a complex term in nature, wherever it is used. In the business sector, it is a complex task for companies and managers to construct some equitable products, and services (Nasse, 2019; Nasse et al. 2020). Most of the manufactured products have always been viewed by customers through a ratio of quality and price. In the world of marketing research, equity is one of the factors for performance, growth (Nasse, 2016), customer satisfaction (Morrisson \& Mathieu, 2003) as well 
as customer retention and customer loyalty (Ladhari, 2005). It is evident to recognize that there have been a lot of research papers which investigate equity and customer loyalty (Olsen, 2002), customer equity (Rust, Lemon \& Zeithaml, 2004), customer equity and customer satisfaction (Ladhari, 2005), equity and repurchase (Nasse, 2015), but less is known about the concept of equity itself in a marketing perspective. The present research seeks to reduce this gap and provide some new thoughtful insights of the concept from researchers' point of views worldwide.

However, what is the understanding of the concept of equity and its theories by researchers in a pure marketing perspective?

The main objective of this paper is to examine the concept of equity and also to underline equity theoretical underpinnings.

\section{Equity Concept Definitions}

\section{LITERATURE REVIEW}

Homans (1961) is one of the earliest researchers that have developed a deep understanding of the concept of equity. For Homans equity is about how a given individual perceives fairness, or distributive justice in an exchange as compared to that individual's investment. Adams (1963) also shows that the concept of equity can result from the comparison that an individual establishes between what this individual perceives as an exchange "outputs" and this individual own contribution to the exchange "inputs". Equity can also be derived from the comparison between what the individual does perceives of an exchange and what other people perceive in this exchange. Adams concludes that when the individual does not perceive equity or fairness in the exchange, s/he can naturally have a behavior that affects the partnership negatively. For Olsen (2002), equity is understood of a history of customer satisfaction and thus, what leads the customer to become loyal. Olsen also views customer satisfaction and customer loyalty as an evidence of equity. In addition, Olsen demonstrates that fairness and satisfaction have positive effects on the customer's engagement towards the offer. Rust, Lemon, and Zeithaml (2004) demonstrate that equity is a measurement tool that provides an opportunity for marketers to build a strong and reliable marketing strategy. Bressy and Konkuyt (2004) point out that fairness in companies management is about getting rid of unfair or illegal practices (that can tarnish their image, reputation or brand image) in order to manage change, and adapt to the risks of good corporate governance, and produce services. Morrisson (2005), basically shows that equity is a dual concept that expresses fairness: the internal dimension of equity and the external dimension of equity. Morrisson specifies that the perception of the level of external equity has an effect on the post recovery consumer satisfaction and then the perception of the level of external equity has a moderating influence on the expected disconfirmation. The concept of equity can be approached as what is fair, appropriate, and adequate. As part of an exchange, equity can be defined as a situation in which the two parties, the party that proposes an offer (the company) and the party that buys this offer (the customer) express satisfaction or dissatisfaction of the observed exchange. Thus, equity implies that each part is treated equally, properly or appropriately. Then, it implies the banishment of unfair practices within an exchange. According to Morrisson (2005, p.3), the concept of equity often stated in marketing relates precisely to the notion of fairness. For Morrisson the concept of external equity is seen in an interference that involves both the company, the customer and another customer, while the concept of internal equity is simply discovered in the interference of exchanges between the 
company and the customer. Still, Morrisson demonstrates that the customer compares the means invested in the exchange and the result obtained through the whole exchange process. The report between means invested and result obtained can then be either negative or positive. External equity is indeed, one of the components of the concept of equity. The definition of external equity by Morrisson (2005, p. 4) is quite clear, perfect and detailed. According to Morrisson, one talks about external equity in a situation of exchange where a customer relates what s/he perceives (the results) and what s/he has spent (the investments) and compares it with that of a reference person who is another customer or a seller. External equity sphere shows that there is an interaction between three (3) actors: the customer, the reference individual (either another customer or a seller) and the company. External equity resulting from the direct comparison between what the individual receives from the company with what one customer receives (or other customers receive) during the business exchange. Therefore, equity requires an external presence of a third party, another customer to enable a meaningful, sententious and significant comparison.

Another component of equity is internal equity. Considering Morrison (2005, p. 4) internal equity consists of a customer making the connection between what s/he perceives (results) and what $\mathrm{s} /$ he spent (investments) in order to appreciate the exchange situation satisfactory or inadequate. When the customer buys a product s/he spends a number of inputs (time, resources or investments). On the basis of this expense, the customer hopes to get a result of some pompous and significant value. The perception of internal equity consists of the comparison between the time, the means invested and the result obtained. If the customer perceives that the result is less than the resources invested, the perception of internal equity is negative. If the customer perceives that the result is greater than the means s/he invested, the perception of internal equity is positive. The perception of internal equity is limited to an interaction between the customer and the company (Morrisson, 2005). The observation that can be made here is that internal equity concerns only two parties: the first party which is represented by the customer and the second party which is represented by the company itself. Of course, in the process of business exchange or customer relationship management, internal equity implies a business circumstance, where there is an interference between only two observable entities: the customer and the company (that is viewed through its brand, and its products or services).

Kotler and Dubois (2003) take along the concept of equity to be more perceptible with the notion of 'fair prices' which takes the management relationships above the mere satisfaction or simple customer loyalty. Thus, Kotler and Dubois, perceive equitable offers in three basic criteria: product quality, induced services quality and fair price. It is in this context that the concept of equity is perceived in the dimension of internal equity. For further, Nasse (2012), Nasse (2016), and Nasse (2019) illustrate equity in a form of a perceived fairness in products offers that is able to induce customers' satisfaction, customers' retention, customers' loyalty and also customers' repurchase.

\section{Equity Underpinning Theories}

- The theory of equity in business exchange: Some researchers such as Homans (1961), Adams (1963), Urbain (1979), Rust et al. (2004), Peretti (2004), Aravindakshan et al. (2004), Morrison (2005), Olsen (2007), Nassè (2019) understand the theory of equity to be a result from the mere comparison between what an individual perceives in an exchange "output, profit" and 
the contribution s/he makes to the exchange "input, investment ". They demonstrate that equity not only affects satisfaction, but they also demonstrate that equity affects loyalty.

- The theory of distributive justice: For some authors such as Sabadie (2000), Kotler and Dubois (2003), Peretti (2004), Juët (2005), Nasse et al. (2020), distributive justice theory stipulates that there should be fairness in any business exchange. Thus, fair exchange is perceived as the adequate balance between the needs of customers and the interests of the company, and it is understood as an avoidance of unfair, biased, imbalanced or illegal business practices.

\section{METHODOLOGY}

Process: The present review of literature has focused on a documentary analysis. The different articles and books that are in line with the topic have been underlined and taken into consideration. The documentary analysis is completed by observations of how customers perceive the different products offers and the prices that are applied on these products.

Data gathering: the data of this research, is a secondary source, what means that it has been collected from various previous research papers that are good quality source. These sources are gathered accessed on internet through the search engines of 'Google, Google scholar, Yahoo, Researchgate, Academia'.

Ethical issues: The articles and the papers that are considered are published in some quality journals. Among these journals there are papers from open access journals and papers from nonopen access journals.

\section{CONCLUSION AND IMPLICATIONS}

The concept of equity, according to the relevant literature has several definitions. Equity has been understood as fairness, distributive justice and the rightfulness. As such, it has been notice through this literature review that there is not a quite common understanding of this concept. However, a common conception of equity refers to the perceptions a customer has about distributive justice from a given product or service. These perceptions may have some intended or unintended effects on the brand. Thus, marketing researchers who are investigating equity related issues should seek to understand adjacent concepts related to fair justice, ethical business practices, business justice and impartial management practices.

\section{REFERENCES}

Adams, J. S. (1963). Towards an understanding of inequity. Journal of Abnormal and Social Psychology, 1(67), 422-436.

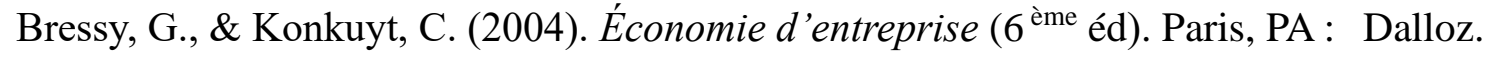

Borg, C. \& Blidner-Knittel, C. (2009). Sales channels connection to marketing communication and customer relationships. Gothenborg, GO: University of Gothenborg.

Homans, G. C. (1961). Social behavior: its elementary forms. London, LO: Routlege and Kegan Paul.

Juët, R. (2005). La boîte à outils du manager (2 ème éd). Paris. PA: Dunod.

Kotler, P. \& Dubois, B. (2003). Marketing management (11 ${ }^{\mathrm{ème}}$ éd). Paris, PA: Pearson.

Ladhari, R. (2005). La satisfaction du consommateur : ses déterminants et ses conséquences. Revue de l'Université de Moncton, 36(2), 171-201.

Morrisson, O., \& Mathieu, J. P. (2003). Représentations du dysfonctionnement d'un service et les réponses de l'entreprise. Dijon, DI: $8^{\text {èmes }}$ Journées de Recherche en Marketing de Bourgogne. 
Morrisson, O. (2005). Influence modératrice de l'équité externe sur la relation disconfirmation des attentes - satisfaction à l'égard des actions de service recovery. Lyon, LY: Université Lyon 3.

Nassè, T. B., Ouédraogo, A., Takougang, S.A.M., Zidouemba, E. (2020). Equity and customer satisfaction in relation to product quality: an evidence from three private companies in Burkina Faso. International Journal of Management \& Entrepreneurship Research, 2(5), 344-352.

Nassè, T. B. (2019). Internal equity and customer relationship management in developing countries: A quantitative and a comparative study of three private companies in Burkina Faso. African Journal of Business Management, 13(1), 37-47.

Nassè, T. B., \& Sawadogo, M. Y. (2019). Internal equity and customer relationship management in subsistence markets: a comparative and a qualitative study of three private companies in Burkina Faso. International Journal of Management \& Entrepreneurship Research, 1(1), 42-58.

Nassè, B. T. (2016). La place de l'équité interne dans la gestion de la relation client. Journal Ouest Africain de Sciences de Gestion, 1(1), 38-54.

Nassè, T. B. (2015). Internal equity as a factor of companies' economic profitability: A comparative study of three private companies in Burkina Faso through a qualitative approach. Saarbrucken, SA: Lambert Academic Publishing.

Nassè, B. T. (2012). The place of internal equity in customer relationship management: an evidence from the Language Learning and Translation Center. Saarbrucken, SA: Lambert Academic Publishing.

Olsen, L. L. (2002). Modeling equity, satisfaction and loyalty in business to consumer markets. Norway, NO : Norwegian school of management.

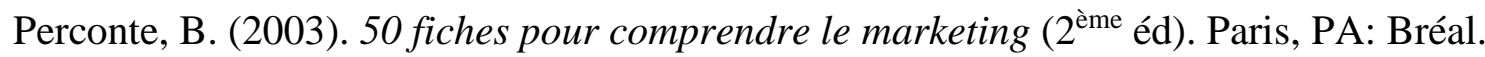

Peretti, J. M. (2004). Les clés de l'équité : enjeu managérial. Paris, PA : Éditions d'organisation

Rust, A. R. T., Lemon, K. N., \& Zeithaml, V. A. (2004). Customer equity: making marketing strategy financially accountable. Journal of Systems Science and Systems Engineering, 13(4), 1-15.

Sabadie, W. (2000). Les apports des théories de la justice au marketing des services. Montréal, MO: $16^{\text {ème }}$ congrès AFM.

Simon, P. (2000). Pour une clarification de la relation entre attitude envers la marque et fidélité à la marque vers la mise en évidence d'un modèle intégrateur. Venezia, VE: Università Ca'Foscari Venezia.

Urbain, C. (1979). De l'équité à la perception et à l'acceptation du prix par le consommateur: la notion de juste prix. Nantes, NA: Université de Nantes.

Zarrad, H. \& Debabi, M. (2010). La négociation des actions marketing entre distributeurs et fournisseurs: Une étude qualitative. Tunis, TU: École Supérieure de Commerce de Tunis, Campus Universitaire de la Manouba.

\section{Conflicts of Interests}

No conflict of interest has been declared by the author. 